\title{
Climate Change and Forest Disturbances
}

VIRGINIA H. DALE, LINDA A. JOYCE, STEVE MCNULTY, RONALD P. NEILSON, MATTHEW P. AYRES,

MICHAEL D. FLANNIGAN, PAUL J. HANSON, LLOYD C. IRLAND, ARIEL E. LUGO, CHRIS J. PETERSON, DANIEL SIMBERLOFF, FREDERICK J. SWANSON, BRIAN J. STOCKS, AND B. MICHAEL WOTTON

\section{$\mathbf{S}$} tudies of the effects of climate change on forests have focused on the ability of species to tolerate temperature and moisture changes and to disperse, but they have ignored the effects of disturbances caused by climate change (e.g., Ojima et al. 1991). Yet modeling studies indicate the importance of climate effects on disturbance regimes (He et al. 1999). Local, regional, and global changes in temperature and precipitation can influence the occurrence, timing, frequency, duration, extent, and intensity of disturbances (Baker 1995, Turner et al. 1998). Because trees can survive from decades to centuries and take years to become established, climate-change impacts are expressed in forests, in part, through alterations in disturbance regimes (Franklin et al. 1992, Dale et al. 2000).

Disturbances, both human-induced and natural, shape forest systems by influencing their composition, structure, and functional processes. Indeed, the forests of the United States are molded by their land-use and disturbance history. Within the United States, natural disturbances having the greatest effects on forests include fire, drought, introduced species, insect and pathogen outbreaks, hurricanes, windstorms, ice storms, and landslides (Figure 1). Each disturbance affects forests differently. Some cause large-scale tree mortality, whereas others affect community structure and organization

\section{Climate CHANGE CAN AFFECT FORESTS}

BY ALTERING THE FREQUENCY, INTENSITY,

DURATION, AND TIMING OF FIRE,

DROUGHT, INTRODUCED SPECIES, INSECT

AND PATHOGEN OUTBREAKS, HURRI-

CANES, WINDSTORMS, ICE STORMS, OR

LANDSLIDES

without causing massive mortality (e.g., ground fires). Forest disturbances influence how much carbon is stored in trees or dead wood. All these natural disturbances interact with human-induced effects on the environment, such as air pollution and land-use change resulting from resource extraction, agriculture, urban and suburban expansion, and recreation. Some disturbances can be functions of both natural and human conditions (e.g., forest fire ignition and spread) (Figure 2).

Virginia H. Dale (e-mail: vhd@ornl.gov) is a senior scientist and Paul J. Hanson is a research scientist in the Environmental Sciences Division at Oak Ridge National Laboratory, Oak Ridge, TN 37831-6038. Linda A. Joyce is a project leader with the USDA Forest Service, Fort Collins, C0 80523. Steve McNulty is the project leader at the Southern Global Change, USDA Forest Service, Raleigh, NC 27606. Ronald P. Neilson is a bioclimatologist and Frederick J. Swanson is a research geologist with the USDA Forest Service, Pacific Northwest Research Station, Corvallis, OR 97331. Matthew P. Ayres is an assistant professor in the Department of Biological Sciences, Dartmouth College, Hanover, NH 03755. Michael D. Flannigan is a research scientist in Forest Fires and Climate Change, Canadian Forest Service, Edmonton, AB T6H 3S5, Canada. Lloyd C. Irland is president, The Irland Group, Winthrop, ME 04364. Ariel E. Lugo is director of the USDA Forest Service, International Institute of Tropical Forestry, Río Piedras, Puerto Rico 00928. Chris J. Peterson is an assistant professor in the Department of Botany, University of Georgia, Athens, GA 30602-7271. Daniel Simberloff is the Nancy Gore Hunger Professor, Department of Ecology and Evolutionary Biology, University of Tennessee, Knoxville, TN 37996-1410. Brian J. Stocks is a senior research scientist in Forest Fire and Global Change, and B. Michael Wotton is a physical scientist in Forest Fire Behaviour, Canadian Forest Service, Sault Ste. Marie, ON P6A 5M7, Canada. Dale, Joyce, McNulty, and Neilson are committee members of the Forest Sector of the National Assessment on Climate Change who are focusing on disturbances. The following scientists who have special knowledge of these disturbances assisted: Ayres (insects and pathogens); Flannigan, Stocks, and Wotton (fires); Hanson (drought); Irland (ice storms); Lugo (hurricanes); Peterson (windstorms); Simberloff (introduced species); and Swanson (landslides). The submitted manuscript has been authored by a contractor of the US government under contract no. DE-AC05-960R22464. Accordingly, the US government retains a nonexclusive, royaltyfree license to publish or reproduce the published form of this contribution, or allow others to do so, for US government purposes. 


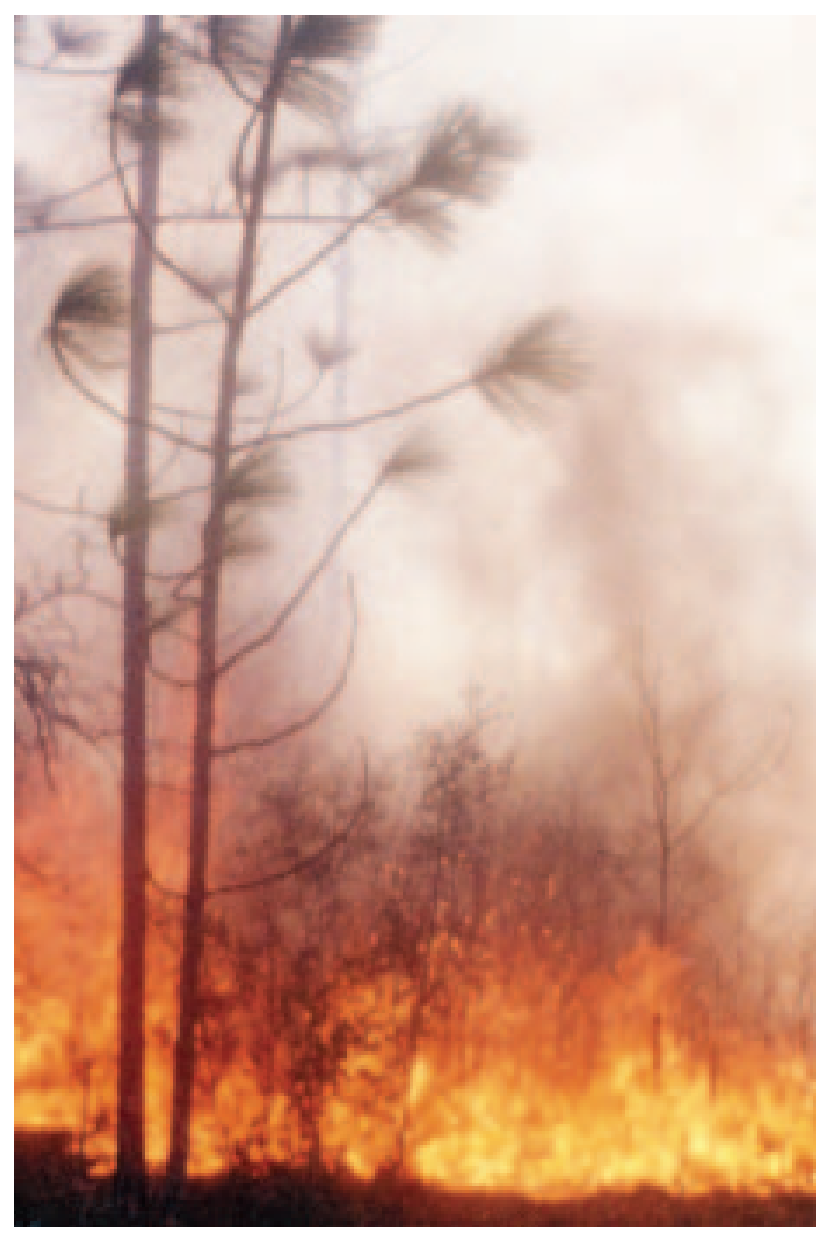

Figure 1. The major disturbance impacts on forests result from fire, drought, introduced species, insect and pathogen outbreaks, hurricanes, windstorms, ice storms, and landslides. Photo: Virginia Dale

Each disturbance has both social and economic effects (Table 1). Estimating the costs of each of these disturbances is very difficult; these estimates for the United States are illustrative only. Of the eight forest disturbances considered, ice storms are the least costly, averaging about $\$ 10$ million and more than 180,000 ha annually (Michaels and Cherpack 1998). Insects and pathogens are the most expensive, with costs exceeding $\$ 2$ billion and 20.4 million ha per year (USDA 1997). The socioeconomic aspects of these damages are only part of the cost. Costs of impacts to ecological services (e.g., water purification) can be large and long term.

This article examines how eight disturbances influence forest structure, composition, and function and how climate change may influence the severity, frequency, and magnitude of disturbances to forests. We focus on examples from the United States, although these influences occur worldwide. We also consider options for coping with disturbance under changing climate. This analysis points to specific research needs that should improve the understanding of how climate change affects forest disturbances.

This paper is one in a series developed by the forest sector of the US National Assessment of the Potential Consequences

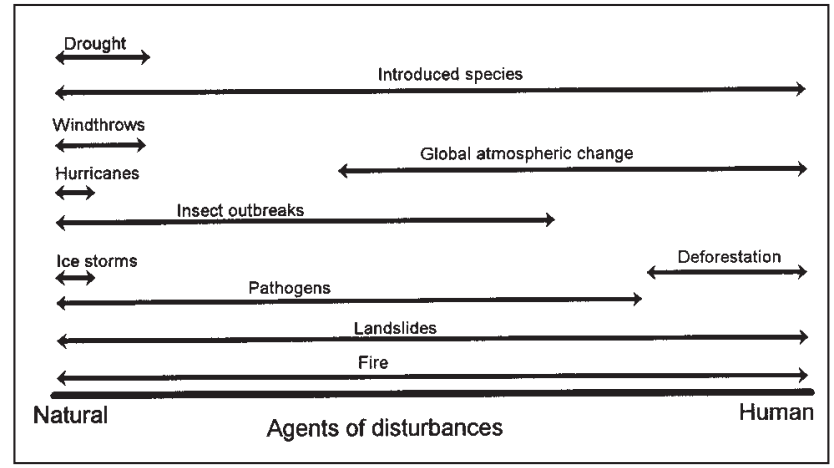

Figure 2. Natural and anthropogenic agents of forest disturbances that result from climate change (modified from Dale et al. 1998a). The length and position of the arrow relates to the extent of natural versus anthropogenic influence on the agent.

of Climate Variability and Change. In examining how forests may be affected by climate change, the Forest Sector Committee divided the topic into four areas (processes, diversity, disturbances, and socioeconomics), each of which is the focus of an article in this issue of BioScience. Impacts of climate changes on aquatic disturbances are critical, but this paper focuses on direct terrestrial impacts. The effects of a rise in sea level, coastal processes, and salinity on terrestrial systems are examined in the coastal sector of the national assessment (NAST 2000).

\section{Past and future climates in the United States}

The Earth has experienced cycles of temperature and precipitation change on a geological scale, but recent evidence points to a large anthropogenic component to current global climate changes (Houghton et al. 1996). Analyses of the last 100 years of climate data for the coterminous United States suggest that the average temperature has risen by $0.5^{\circ} \mathrm{C}$ and that precipitation has increased 5\%-10\% (NAST 2000); observations also indicate that there has been some increase in precipitation and temperature extremes (Easterling et al. 2000). To look at future climates, scenarios from two of the newer, transient general circulation models (GCMs)—one developed by the Hadley Center in the United Kingdom (HADCM2SUL) and one by the Canadian Climate Center (CGCM1) - have been selected for this national assessment (MacCracken et al. 2000). These transient GCMs simulate atmospheric dynamics under a gradual increase in greenhouse gas concentrations from about 1895 to 2100 and produce scenarios (precipitation patterns, temperature changes, and so on) that forest-process and biogeography models use to examine transient community and ecosystem dynamics under climate change (Aber 2001, Hansen et al. 2001).

These two climate scenarios present a useful contrast for future climates. The HADCM2SUL produces relatively modest temperature increases over the United States (approximately $2.6^{\circ} \mathrm{C}$ ) and large precipitation increases (about 20\%); the CGCM1 simulates larger temperature increases 
Table 1. Relative areal extent and economic cost of current disturbances in the United States.

\begin{tabular}{lcc}
\hline Disturbance & $\begin{array}{c}\text { Average annual impact area } \\
\text { (ha) }\end{array}$ & $\begin{array}{c}\text { Average annual economic cost } \\
\text { (millions of dollars) }\end{array}$ \\
\hline & & $261^{\mathrm{b}}$ \\
Fire & $450,000^{\mathrm{a}}$ & $700^{\mathrm{d}}$ \\
Hurricane & $1,200,000^{\mathrm{c}}$ & $154^{\mathrm{f}}$ \\
Tornado & $450,000^{\mathrm{e}}$ & $>10^{\mathrm{g}}$ \\
Ice & $>180,000^{\mathrm{g}}$ & $1,500^{\mathrm{i}}$ \\
Insects and pathogens & $20,400,000^{\mathrm{h}}$ & $60^{\mathrm{j}}$ \\
Exotic species & Nationwide & $1,000^{\mathrm{k}}$ \\
Landslide & 100,000 & Severity dependent \\
Drought & Nationwide & \\
\hline
\end{tabular}

aData from Ruiz (1996).

'brom 1989 to 1994, fires destroyed 454,000 ha of US forests each year (Ruiz 1996). In 1994, the United States had 661,000 ha of forest fires with a total loss of $\$ 380$ million, or $\$ 575$ per ha burned. We assume that the geographic distribution of the 1994 fires represents the average distribution of fires.

'Based on the 1.8 million ha of South Carolina forest destroyed by Hurricane Hugo in 1989 and on the fact that an average of 0.67 major hurricanes per year struck the US mainland from 1900 to 1996 (Hebert et al. 1996).

dObtained by multiplying the $\$ 700$ in annual damage that occurs per year (Marsinko et al. 1997) by a 0.67 annual frequency.

eFrom Fujita (1971), we calculate an average area of damage to be 975 ha, multiply this value by the number of forest tornadoes in each region, and sum over all regions to obtain a first-order approximation of the total annual damage to forests by tornadoes.

${ }^{f}$ Across the southern United States, average harvest rotation length is 30 years, while across the North and Rocky Mountain region it is 70 years. Tornadoes destroy both the current year and accumulated previous years' growth. Annual returns of forestland range from $\$ 2.68$ per ha in the Rocky Mountains to $\$ 23.46$ per ha in the South (USDA 1990). Given that tornadoes affect all forest age classes, tornadoes destroy 35 years' worth of growth in the North and Rocky Mountains while destroying 15 years' worth of growth in the South. Assuming that the age classes are equally distributed and that downed timber is not salvageable, the total annual impact of tornadoes is approximately $\$ 154$ million.

gBased on January 1998 ice storm damage across New England, with a 100-year frequency (Michaels and Cherpack 1998).

${ }^{n}$ The regional extent of insect- and pathogen-related forest damage is 20.4 million ha (USDA 1997). However, not all of the trees within this forested area are destroyed. Instead, insects and pathogens within this region annually kill some trees while reducing productivity for many others. Major insect pests include the southern pine beetle (3.0 million ha), gypsy moth (up to 2.6 million ha), other spruce and pine beetles (up to 1 million ha), and hemlock woody adelgid (areal extent unknown). Major pathogens include dwarf mistletoe (11.7 million ha), fusiform rust (about 1.8 million ha), white pine blister rust (areal extent unknown), and anthracnose (areal extent unknown).

${ }^{i} \mathrm{CP}$ Harausz, personal communication, 2000.

jFrom Kräuchi (1993).

kFrom Schuster (1996).

(approximately $5.0^{\circ} \mathrm{C}$ ) and similar model precipitation increases over the coterminous United States in the next 100 years (NAST 2000). The ecological models associated with the national assessment incorporate fire and drought disturbances, and we report the implications of these climate scenarios on these disturbances. The technology to incorporate other disturbances, such as windstorms or invasive species, is only now emerging. Therefore, the analyses we present here are based on new technology or are simply our best inference based on ecological models, literature surveys, or our professional judgment.

\section{Climate influences on forest disturbances}

A review of how each disturbance is influenced by climate, affects forests, and might be exacerbated by climate change provides a background for examining ways to cope with the impacts of climate change. The effects of each disturbance are partly tempered by prior adaptations. For example, species present in a forest reflect past disturbances. Droughty sites typically support species that survive well under dry conditions with uncertain rainfall. Sites that have frequent fires contain gymnosperm species with serotinous cones. Thus, if climate change alters the distribution, extent, frequency, or intensity of any of these disturbances, large impacts (such as loss of species regeneration) could be expected. The effects on species or communities already at the margin of their range may be particularly severe.

Fire. The frequency, size, intensity, seasonality, and type of fires depend on weather and climate in addition to forest structure and composition. Fire initiation and spread depend on the amount and frequency of precipitation, the presence of ignition agents, and conditions (e.g., lightning, fuel availability and distribution, topography, temperature, relative humidity, and wind velocity).

Fire effects on forests include acceleration of nutrient cycling, mortality of individual trees, shifts in successional direction, induced seed germination, loss of soil seed bank, increased landscape heterogeneity, changes in surface-soil organic layers and underground plant root and reproductive tissues, and volitalization of soil nutrients (Whelan 1995). Erosion can occur where soil disturbance accompanies fire (e.g., during fire fighting or timber salvage operations). Fire affects forest value for wildlife habitat, timber, recreation, and, through smoke, human health.

The rapid response of fire regimes to changes in climate (Flannigan et al. 1998, 2000, Stocks et al. 1998) can potentially 

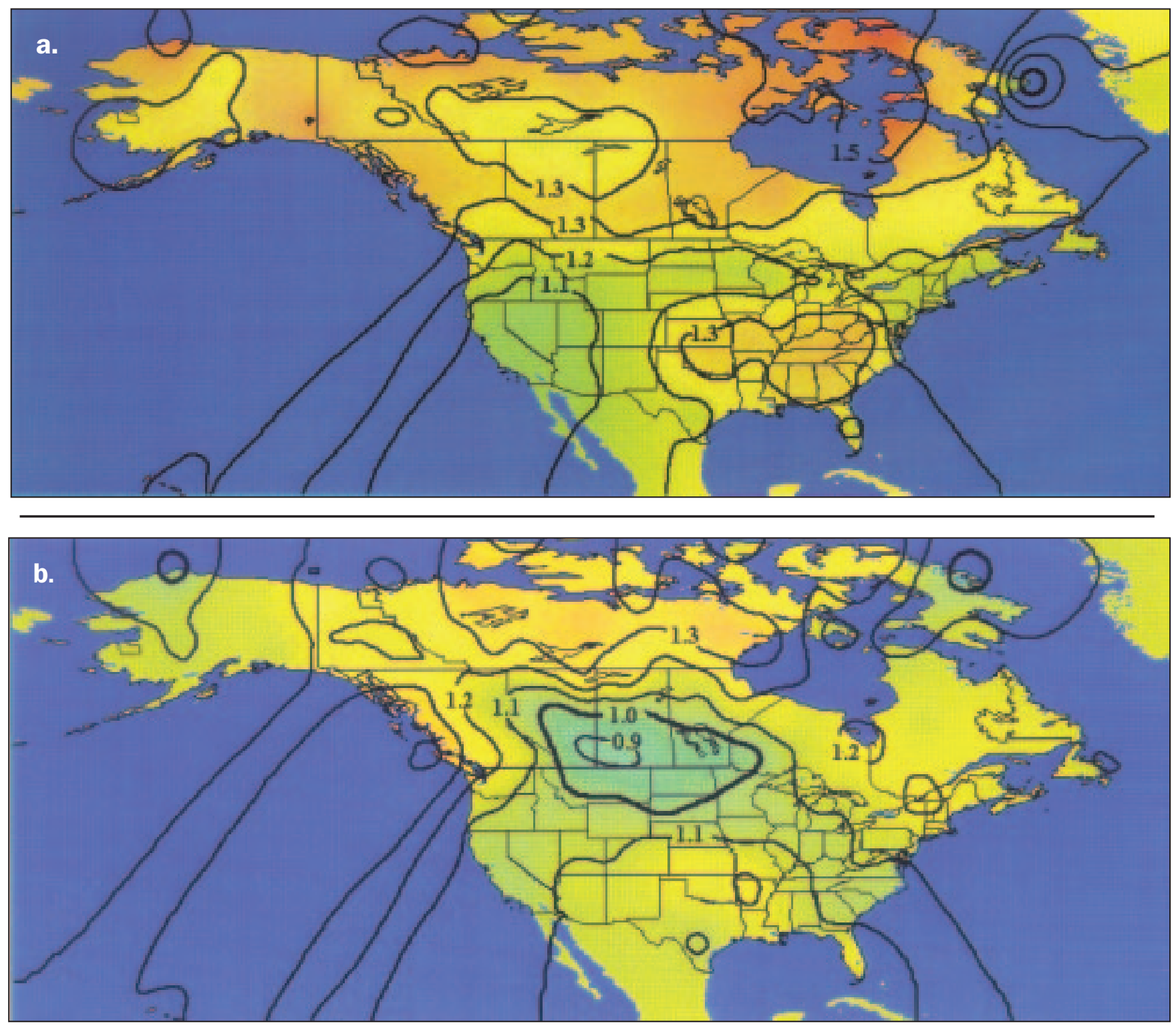

Figure 3. The ratio of the mean seasonal severity rating (SSR) between 2060 and the present day using (a) the Canadian GCM and (b) the Hadley GCM in the fire model described by Flannigan et al. (1998). The figures are a ratio of the future divided by the present, so that isolines of 1.0 mean no change, ratios greater than 1.0 mean an increase in SSR, and ratios less than 1.0 mean a decrease in SSR. The SSR is a measure of the fire weather severity and is a rough indicator of area burned. The average SSR for 1985 to 1994 was used for the present value, and an average for 2055-2064 for the 2060 value.

overshadow the direct effects of climate change on species distribution and migration. Modeling results predict great variation in future fire-weather patterns for the northern portion of North America (Figure 3). The seasonal severity rating (SSR) of fire hazard increases over much of North America under both the HADCM2SUL and the CGCM1 scenarios. The wetter Hadley scenario produces some small decreases in SSR for the Northern Great Plains, and increases are generally less than $10 \%$ over most of the rest of the continent. Some fire history studies suggest that the frequency of fire can decrease despite warmer temperatures because of increased precipitation (e.g., Bergeron and Archambault 1993). The warmer and drier
CGCM1 produces a $30 \%$ increase in SSR for the southeastern United States and Alaska, with about 10\% increases elsewhere. These scenarios suggest an increase in fire intensity and a $25 \%-50 \%$ increase in the area burned in the United States. In addition, recent results from the MC1 model, which is described by Neilson and Drapek (1998), show an increase in area and biomass burned under both scenarios. This model includes an interaction with $\mathrm{CO}_{2}$ concentrations, which, through increased $\mathrm{CO}_{2}$ fertilization and increased water-use efficiency, produces more biomass and thus more fuel, contributing to more and larger fires under a highly variable climate that has dry years interspersed with wet periods. 
Drought. Droughts occur in nearly all forest ecosystems. Drought effects are influenced by soil texture and depth; exposure; species present; life stage; and the frequency, duration, and severity of drought. Droughts occur irregularly in forests of the humid regions east of the Mississippi River and in the superhumid Pacific Northwest. Droughts occur annually at the end of the growing season in forests at the midcontinental prairie-forest border, where annual precipitation ranges from $600-1000 \mathrm{~mm}$, or within humid regions that have shallow or rocky soils. Seasonal summer droughts are experienced by western interior dry forests that depend on winter precipitation, such as forests in the semiarid plains and intermountain regions of the western United States. In some regions, droughts last several years.

The primary immediate response of forests to drought is to reduce net primary production (NPP) and water use, which are both driven by reduced soil moisture and stomatal conductance. Under severe conditions, plants die. Small plants, such as seedlings and saplings, are usually the first to die and can succumb under moderate conditions. Deep rooting and stored carbohydrates and nutrients make large trees susceptible only to severe droughts. Secondary effects also occur. When reductions in NPP are extreme or sustained over multiple growing seasons, increased susceptibility to insects or disease is possible, especially in dense stands (Negron 1998). Drought can also reduce decomposition processes, leading to a buildup of organic matter on the forest floor that may increase fire frequency or intensity or reduce nutrient cycling.

The consequences of drought depend on annual and seasonal climate changes and on whether the current drought adaptations are sufficient to confer resilience to new conditions (Hanson and Weltzin 2000). Forests tend to grow to a level of maximum leaf area that nearly fully uses soil water during the growing season (Neilson and Drapek 1998). A small increase in growing-season temperature could increase evaporative demand, triggering moisture stress. New results from two models described by Daly et al. (forthcoming), MAPSS and $\mathrm{MC1}$, suggest that this mechanism may cause future increases in drought stress in the Southeast, southern Rockies, and parts of the Northwest. The MC1 model indicates that the Prairie Peninsula and Great Lakes region, parts of the Northwest, and the Gulf Coast could experience drought stress within two decades, even though these regions may become wetter in later decades.

Insect and pathogen outbreaks. Climate influences the survival and spread of insects and pathogens directly, as well as the susceptibility of their forest ecosystems. Changes in temperature and precipitation affect herbivore and pathogen survival, reproduction, dispersal, and distribution. Indirect consequences of disturbance from herbivores and pathogens include elimination of nesting trees for birds and negative effects on mycorrhizal fungi (Gehring et al. 1997, Ayres and Lombardero 2000). Other indirect effects include the impacts of climate on competitors and natural enemies that regulate the abundance of potential pests and pathogens.
Changes in the intensity and frequency of herbivore and pathogen damage in forests can have a range of effects. Most tree species support a community of other organisms, so the loss of any tree species can significantly reduce overall biodiversity. Such a loss occurred when chestnut blight almost completely eliminated chestnut trees (Opler 1979); the dieoff of Fraser fir (Abies fraseri) caused by balsam woolly adelgid (Adelges piceae) also raises concerns. Herbivore and pathogen damage to trees can increase understory plant diversity (Stone and Wolfe 1996); the overall abundance and diversity of birds (Bennetts et al. 1996); and the diversity of predators, parasitoids, and detritivores (Savely 1939).

Because climate change can both directly and indirectly affect herbivores and pathogens through various processes, the ultimate effects on patterns of disturbance include increased disturbance in some areas and decreased disturbance in others. For example, an increase in the interannual variation in minimum winter temperatures is expected to favor more northerly outbreaks of southern pine beetles but could reduce more southerly outbreaks (Ungerer et al. 1999). Similarly, decreased precipitation and increased evapotranspiration should boost tree secondary chemical metabolism (and, therefore, resistance to pests) in forests that currently suffer modest growing-season water deficits (Reeve et al. 1995).

If global warming shifts species abundances, there may be associated shifts in herbivory. Compared to the cooler Paleocene, the Eocene had a greater diversity of herbivores and higher attack rates on the most abundant tree species (Wilf and Labandeira 1999). Increased warming would most likely increase the diversity of insects at higher latitudes. Because insects typically migrate much faster than trees, many temperate tree species are likely to encounter nonnative insect herbivores that previously were restricted to subtropical forests.

Introduced species. Introduced species can affect forests through herbivory, predation, habitat change, competition, alteration of gene pools via hybridization with natives, and disease (as either pathogens or vectors). Introduced species can alter the diversity, nutrient cycles, forest succession, and fire frequency and intensity of some ecosystems. The effects of introduced species should be considered concurrently with changes in native species distribution and abundance that occur as a consequence of climate change (Hansen et al. 2001). The impact of introduced species on ecosystems is influenced by such climatic factors as temperature, drought, and cloud cover (Ayres 1993). Invasion biology is not yet adept at forecasting impacts of invasions (Williamson 1999). The complex interactions among introduced species, native communities, managed and intensely harvested forests, and climate change compound this forecasting problem (Simberloff 2000).

The ultimate ranges of introduced species are largely determined by climate and human activities. Climate change will modify the distributions of many introduced species. Developmental rates will be modified by temperature change. For example, laboratory studies of balsam woolly adelgid grow- 
ing under various temperature conditions provided the basis for simulations that suggest that temperature-induced changes in the population dynamics of the insect significantly affect Fraser fir survival (Dale et al. 1991).

The great majority of introduced species do not survive (Williamson 1999). Many fail because the climate is unsuitable at their points of arrival. Thus, a changed climate will lead to a different mix of surviving and failing species. In general, one might expect a larger fraction of survivors when the climate is warmer; introduced species comprise a far larger fraction of the biota in the warmer areas of the United States (Simberloff 1997).

Increased $\mathrm{CO}_{2}$ can directly influence introduced plants through enhanced photosynthesis, but at different rates for different species. Resistance of trees to introduced herbivores is sensitive to both climate and $\mathrm{CO}_{2}$ concentrations. Climate change, in concert with $\mathrm{CO}_{2}$ concentration and nitrogen deposition, affects leaf nitrogen, which in turn influences herbivory.

Hurricanes. Hurricanes disturb forests of the eastern and southern coastlines of the United States, as well as those of the Caribbean islands and the Atlantic coast of Central America. Ocean temperatures and regional climate events influence the tracks, size, frequency, and intensity of hurricanes (Emanuel 1987). An average of two hurricanes make land every 3 years in the United States (Hebert el al. 1996). Global warming may accelerate the hydrologic cycle by evaporating more water, transporting that water vapor to higher latitudes, and producing more intense and possibly more frequent storms (Emanuel 1987, Walsh and Pittock 1998). However, other variations may override possible increases in hurricane frequency (Lighthill et al. 1994).

Changes in the global hydrologic cycle and temperature will influence hurricane formation, but we cannot yet predict the direction and magnitude of change. Sea-surface temperatures are expected to rise, with hotter temperatures expanding to higher latitudes (Royer et al. 1998, Walsh and Pittock 1998). Most studies point to an increase in hurricane frequency (Royer et al. 1998). However, even if frequency does not increase, it is likely that intensity and possibly duration of individual storms will increase because of the warming of the air and ocean, sources of energy for a hurricane (Emanuel 1987, Walsh and Pittock 1998).

The effects of hurricanes on vegetation include sudden and massive tree mortality, complex patterns of tree mortality (including delayed mortality), and altered patterns of forest regeneration (Lugo and Scatena 1996, Lugo 2000). These changes can lead to shifts in successional direction, higher rates of species turnover, and opportunities for species change in forests, which can in turn increase landscape heterogeneity, produce faster biomass and nutrient turnover, and result in lower aboveground biomass in mature vegetation (Lugo and Scatena 1995). Hurricanes can also result in buried vegetation and carbon sinks.
Windstorms. Small-scale wind events are products of mesoscale climatic circumstances and thus may be affected by climate changes, although the type and amount of alteration in windstorm characteristics cannot be predicted because these smaller-scale events are below the resolution of today's GCMs. Yet, tornadoes, downbursts, and derechos (a series of storm cells along a squall line) are probably the most important agents of abiotic disturbance to eastern deciduous forests (Peterson 2000). These disturbances can create very large patches of damage: A windstorm on 4 July 1999 in the Boundary Waters Canoe Area of Minnesota flattened roughly 250,000 acres of forest (Minnesota Department of Natural Resources press release, 12 July 1999). Windstorms can cause heavy mortality, produce canopy disruption, reduce tree density and size structure, and change local environmental conditions. Consequently, the disturbance may trigger advance regeneration, seed germination, and accelerated seedling growth (Peterson and Pickett 1995). These effects can change successional patterns, gap dynamics, and other ecosystem-level processes. The relationship between wind strength and severity of disturbance is not constant across different forests and species; although shallow-rooted species and thinned stands may be especially vulnerable to wind events, multiple factors influence tree response to high winds.

Berz (1993) suggests that increased intensity of all atmospheric convective processes will accelerate the frequency and intensity of tornadoes and hailstorms. Consistent with this view, Karl and colleagues (1995a) found that the proportion of precipitation occurring in extreme thunderstorm events increased in the United States from 1910 to 1990, and Karl and colleagues (1995b) further suggest that the climate of the United States has become more extreme (in terms of temperature and precipitation anomalies) in recent decades. Thus, it appears that the thunderstorm conditions that contribute to tornado formation have increased and are likely to continue increasing under projected climate changes. Furthermore, Etkin (1995) found a positive correlation between monthly tornado frequency and mean monthly temperature in western Canada, and inferred that this relationship suggests increased tornado frequency under a warmer climate scenario. Despite these inferences about tornado frequencies and the direct data on thunderstorm trends, understanding of tornado genesis is still inadequate to allow a direct forecast of how climate change will affect the frequency or severity of windstorms in the next century (Chuck Doswell [National Severe Storms Laboratory], personal communication, 2000).

Ice storms. Ice storms are caused by rain falling through subfreezing air masses close to the ground; those air masses supercool the raindrops, which freeze on impact. Ice accumulation can vary dramatically with topography, elevation, exposure, and areal extent of the region over which conditions favor glaze formation. Ice storms occur throughout the United States except along the southwestern borders and parts of the plains, but the frequency and severity of ice storm events increase toward the northeastern US borders. However, the 
historic record of ice-storm events over large areas has not been consistent or precise, with rigorous measurements of ice accumulation.

Ice storms affect trees, forests, and forested landscapes in different ways. Ice damage to trees can range from severing a few twigs, to bending stems, to moderate crown loss, to outright breakage of trunks. Depending on stand composition, amount and extent of ice accumulation, and stand history, damage to stands can range from light and patchy to total breakage of all mature stems (Irland 1998). Effects on forest stands include shifts in overstory composition in favor of more resistant tree species, loss of stand growth until leaf area is restored, and damage to stem form (Irland 2000). Damaged stems are then more susceptible to the impacts of insects and disease (Smith 2000). Recently thinned stands can be highly vulnerable because crowns have spread into the new space but branch strength has not developed. Several tree species can survive within areas frequented by ice storms. Though weather conditions producing ice storms are well understood, it is unclear how changes in climate will affect their frequency, intensity, regional location, or areal extent. However, atmospheric warming will most likely shift the locations of prevailing ice storms northward.

Landslides. Both slow and rapid movements of soil, rock, and associated vegetation are triggered directly by climate factors and indirectly by climate-influenced processes (e.g., stream-bank erosion) and by nonclimate factors such as earthquakes and volcanism. Triggering climatic events include snowmelt and intense rainfall, including that associated with hurricanes. Landslide frequency and extent are influenced by precipitation amount and intensity; snow accumulation, melt rate, and distribution; and roads and other land uses. The potential for a site to slide is influenced by slope steepness, properties of soil and rock, and hydrologic factors. Vegetation influences the likelihood of sliding through the soilstabilizing effects of root systems and the effects of vegetation structure and composition on hydrology. Landslides remove soil and vegetation from steep slopes and damage forests on gentler slopes where landslide deposits come to rest. Landslides in forest landscapes can also damage aquatic resources and threaten public safety. Yet it is important to recognize that landslides are natural components of terrestrial and aquatic ecosystems.

Climate-change effects on landslides reflect changes in the delivery of water to soils through altered precipitation and snow hydrology (Buma and Dehn 1998). Because climate change is expected to vary geographically and with elevation, landslide responses will vary with similar complexity. Landslides are expected to be less frequent in areas where GCM scenarios predict reduced overall precipitation or reduced snowmelt because of warming trends, limiting snow accumulation (Buma and Dehn 1998, Dehn forthcoming). In the Pacific Northwest, much of the small, rapid landsliding occurs during rain-on-snow events in a broad elevation band where snow accumulates and melts several times in an aver- age year. A simple warming without change in overall annual precipitation would be expected to result in reduced sliding by limiting the amount of snow (and its associated snowmelt) available to augment the rainfall reaching the soil. The most socially and ecologically significant landslides are triggered by intense precipitation. Thus climate change that increases storminess, and hence soil saturation, will increase landslide occurrence.

Interactions among disturbances. Many disturbances are cascading. Drought often weakens tree vigor, leading to insect infestations, disease, or fire. Insect infestations and disease promote future fires by increasing fuel loads, and fires promote future infestations by compromising tree defenses. Increased fire intensity or extent would enhance the potential for landslides. Also, changes in land use, forest management, and atmospheric chemistry can interact with these natural disturbances. For example, harvest and road establishment in landslide-prone areas coupled with increased wetness could result in more landslides. In the southern Appalachians, ozone exposure coupled with infestations of exotic insects and climate change may increase Fraser fir mortality and red spruce stress. In some cases, however, the combination of disturbances may ameliorate impacts. Under droughty conditions, stomata tend to close, reducing the effects of high ozone exposure.

Nevertheless, when ecosystems experience more than one disturbance, the compounded effects can lead to new domains or surprises (Paine et al. 1998). A new domain is entered when the system has not recovered from the first disturbance before a second perturbation occurs, leading the system to a new long-term condition. For instance, the combination of climatically driven wildfires, fragmentation caused by agricultural settlement, and logging in the boreal forest has resulted in significant and unprecedented changes in forest composition (Weir 1996). Invasive nonnative species are sometimes able to modify existing disturbance regimes or introduce entirely new disturbances (Mack and D'Antonio 1998). Under climate change, these compounded interactions may be unprecedented and unpredictable. They are likely to appear slowly and be difficult to detect because trees live for so long.

\section{Strategies for dealing with forest disturbances}

Coping strategies for forests are influenced by the value of the forest, the naturalness of the disturbance, and the range of acceptable management options. Often the least ecologically disruptive response after a disturbance is no action at all, but managers or society usually call for some type of cleanup or restoration, even when such action may retard recovery (Dale et al. 1998a). The value and management goals for the forest dictate how many resources can be allocated to its management. These values can change, as is illustrated by the revision of burn policy to recognize fire as a natural part of forest development that should not always be controlled. 


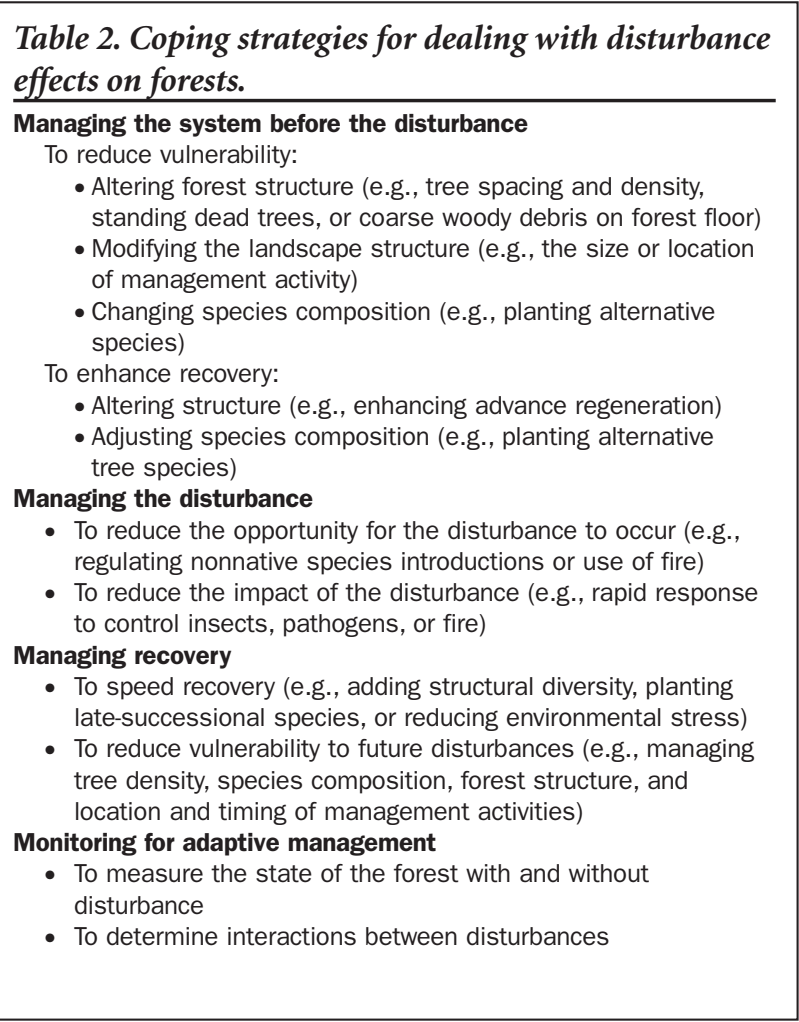

The ability to manage for these eight disturbances varies greatly. However, current understanding of the disturbance nearly always provides some guidance for management under a future changed climate. Coping strategies for one disturbance type are often appropriate management responses to other disturbance types. For example, the removal of dead or dying trees and downed woody debris can reduce the risk of fire as well as alter insect and disease dynamics. Density management can reduce drought stress as well as alter insect population dynamics, but it could make forests more susceptible to wind. Thus, management effects are not always positive. Strategies for coping with disturbances in forests may also vary regionally. No matter where they are carried out, however, these practices often take 50-100 years to convert a landscape, and they are difficult to implement on inaccessible sites or in reserves.

We organize the coping strategies into several categories: managing before the disturbance, managing the disturbance itself, managing the recovery, and monitoring for adaptive management (Table 2). These options are presented independent of climate-change effects but with the understanding that climate may alter the disturbance regime.

Managing before a disturbance. Before a disturbance occurs, forests can be managed to reduce vulnerability or to enhance recovery. In both cases, management actions can alter the structure or the composition of the forest. In situations where the goal is to reduce the chance of future disturbances, adjustments to forest structure can be useful. For example, species or individual trees susceptible to ice or wind storms can be removed, as is common in cities. In addition, tree spacing and density can be altered to reduce susceptibility to drought. However, dead woody debris has numerous benefits (Harmon et al. 1986), and its extensive removal can affect the biota and nutrient cycling. Managers can also change species composition to reduce the vulnerability of forests to disturbances. Tree species that are less vulnerable to fire, droughts, wind, insects, or pathogens can be planted or maintained. For example, the colonization of phloem-feeding insects, such as bark beetles, is partially controlled by the ability of the tree to produce oleoresin, which is under genetic control. So, planting selected tree species and genotypes with relatively high oleoresin could limit insect outbreaks.

Landscape structural changes can also reduce the chances that future disturbances will damage the forest. The pattern of clear-cutting influences the potential for windstorms to blow down trees, because destructive winds are more prevalent along the edge of a cut (Savill 1993). And the placement of roads can influence the likelihood of future landslides and the spread of wildfire.

Management can be designed to reduce the opportunity for disturbance to occur. Examples are regulations that limit the introductions of nonnative species, the imposition of burning restrictions, and the use of controlled burns to reduce fuel loads. Trees can be planted that are less susceptible to disturbance. Species that promote disturbances can be removed. Density of trees can be managed to reduce the potential for future insect outbreaks or storm damage. Finally, roads can be designed to reduce the potential for landslides.

Other management actions can enhance forest recovery. Forest structure can be modified to speed up the successional process in the event of a disturbance. Alternatively, species composition can be adjusted to promote recovery. For example, in areas likely to experience a disturbance, trees with salvage value can be planted.

Managing the disturbance. Some disturbances, such as fire, insects, disease, and drought, can be managed during the disturbance through preventive measures or manipulations that affect the intensity or frequency of the disturbance. Alternatively, the disturbance can be managed to reduce its impact. A common way to control outbreaks of the southern bark beetle is to be on the alert for sites experiencing some beetle damage, then to cut those trees quickly to reduce the size of the area affected. Fire control is another example of a management action to reduce the impact of a disturbance.

Managing the recovery. Recovery efforts can focus either on managing the state of the system immediately after the disturbance (e.g., salvage logging) or managing the ongoing process of recovery (e.g., planting and reseeding). Recovery efforts need careful consideration of the long-term impacts because such actions can damage soils and residual trees. Stands can recover naturally without any removal of the dead or damaged trees.

Recovery actions can be designed to speed recovery. In the aftermath of a disturbance, recovery can be enhanced by 
Table 3. Research questions about how disturbances affect forests in the face of climate change. (The numbers refer to the interactions indicated in Figure 4.)

1. Improved understanding of climatological conditions that initiate disturbances

What are the average and range of climate-change predictions?

What information about climate and weather forecasts are needed to improve both short- and long-term predictions of disturbance effects on forests?

How do interactions between forest structure and function and climate affect disturbances?

How does climate variability interact with the temporal and spatial variability of forest disturbances?

2. Better information on how disturbances and land-use changes affect climate

How do changes in forest structure caused by disturbance influence weather and climate?

Can hurricanes transport enough heat and moisture to alter climate?

3. Quantifying the impacts of disturbances on forests

What are the average and range of the frequency, intensity, and spatial extent of forest disturbances?

What are the major environmental factors affecting forest disturbance regimes?

What are the major impacts of disturbance on forests?

What patterns of species composition and yield are altered by disturbances (especially at the margin of species ranges)?

What are the long-term effects of a disturbance, and how can they be quantified?

4. Interactions among forest disturbances and management

What information is needed to understand the response of a forest to multiple disturbances?

How do forest disturbances interact?

What options exist for managing forests in the face of climate change?

How should forests be monitored to best inform management of impending changes?

adding structural elements that create shade or other safe sites necessary for reestablishing vegetation or that serve as perches for birds (and thus places where seeds would be dispersed). Alternatively, late successional species can be planted to speed up succession. Finally, additions of water or nutrients can reduce environmental stress and facilitate restoration. Recovery can also be managed to reduce vulnerability to future disturbances.

Monitoring for adaptive management. A monitoring program should be used to determine how disturbances affect forests and to continually update our understanding of how climate change is potentially influencing the disturbance regimes. Monitoring can be designed to measure the state of the forest with and without disturbance under different management activities or to identify potential risks of forest disturbances. Such information is used to inform management of the potential outcomes of management actions.

Although many coping strategies associated with these disturbances could be incorporated into current forestmanagement practices regardless of climate change, the potential changes in climate may create a novel disturbance. For example, climate change may allow the migration of nonindigenous species into a forest, and current understanding of interactions and coping strategies may not apply to the resulting competitive interactions between nonindigenous and native species. Adaptive management approaches management as a continual learning process (Walters 1986). The continued monitoring of ecosystem structure and function could be part of the coping strategy to address the likely surprises. The impacts of insects and pathogens are already monitored through the Forest Health Program, and weather and fuel moisture are monitored to assess the risk of fire during the fire season. However, few surveys quantify the extent and severity of damage from wind and ice storms or landslides.

Information from monitoring programs could be used to update risk assessments in management plans and prescriptions in an adaptive-management sense. A risk-ranking system could identify aspects of the forest most susceptible to disturbance under a changing climate. In conjunction with spatially explicit modeling of the site under various scenarios of disturbance impacts, a risk map could be created to identify sites most in jeopardy (Dale et al. 1998b).

\section{Research needs}

A key feature of this analysis is the realization of our lack of knowledge in many critical areas. The numbered aspects of Figure 4 depict major interactions about which more information is needed. We determined the key research needs for each disturbance and then organized the questions that must be resolved into the six topics discussed below. Examples of broad research questions are given in Table 3. Such research will lead to better management decisions.

Understanding climatological conditions that initiate disturbance. Accurate projections of climate effects of disturbances require improved climate and weather forecasts. The projections should include not only average climate conditions but also their range and variance. Short-term weather forecasts will be needed to predict drought occurrences for existing forests. For long-term climate change projections, improved resolution in climate models is needed so that regional patterns can be projected. 


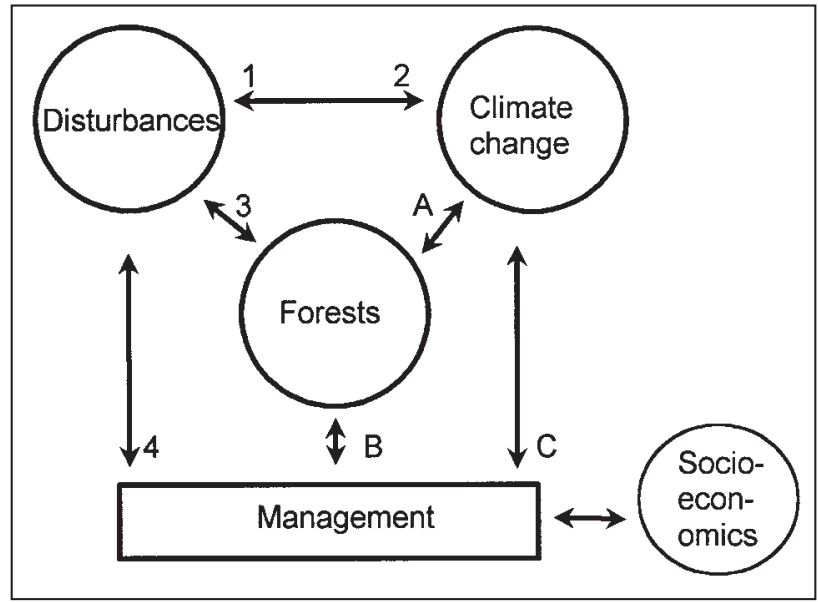

Figure 4. Interactions among disturbances, climate change, forests, and management strategies. The numbered arrows are the focus of research questions addressed in Table 3. The lettered interactions are covered in other analyses; $A$ and $B$ are discussed elsewhere in this issue of BioScience, and $C$ is discussed by Houghton et al. (1996). Management would include information from the social and political arenas as well as feedbacks from disturbances, climate change, and the forests themselves.

We have limited understanding of what climatological conditions lead to some disturbances. Improved understanding of local meteorological events that spawn tornadoes is needed, as well as improved projections of conditions that foster thunderstorms. Our ability to predict the occurrence of fires and hurricanes has benefited from research that allows managers to focus their attention on sites most likely to be disturbed. However, some disturbances result from interactions between ecological and climatological conditions that are often poorly understood. For example, better monitoring is needed to improve the characterization of ice accumulation in relation to storm characteristics and associated weather, especially the delineation of areas by amount of ice accumulation. Once the relationship between climate and disturbances has been quantified, more-accurate predictions of disturbances can be developed to minimize their impact.

\section{Understanding the effects of disturbances on mi-} croclimate. Because land-cover patterns can affect atmospheric circulation and cloud formation (Segal et al. 1988), changes in forest structure in the aftermath of fire, wind or ice storms, hurricanes, landslides, drought, and pest outbreaks may alter weather or climate conditions. This interaction needs to be studied and better understood.

\section{Quantifying impacts of disturbances on forests.} There is a paucity of basic information on the frequency, intensity, and spatial extent of some disturbances and their impacts on forests. This problem is especially severe for land- slides, ice storms, and small wind events. For example, reconstructive studies should be done to determine the longterm influence of successive ice storms on forests. Such analysis also allows exploration of interactions between disturbances and delayed responses.

Research should identify herbivores and pathogens that are likely to be key agents of forest disturbance in the next 50 years. Integrated continental surveys are needed to determine the sensitivity of different types of pests and diseases to environmental change and the potential for increased outbreaks of insect herbivores and pathogens at the margins of their existing ranges.

Interactions between forest disturbances and management. Our ability to manage forests now as well as under climate change rests on our understanding of how forests respond to multiple disturbance events. A better understanding of interactions among fire, hurricanes, and biological disturbances (such as insects, pathogens, and introduced species) would improve our long-range predictions about forest succession and ecosystem dynamics and would lead to better prediction of conditions under which one event would affect the response to a subsequent one. This understanding, however, is complicated by the diverse goals of forest management (e.g., fiber products, wildlife habitat, biodiversity, and recreation).

Some management practices have been developed to cope with the physical disturbances of droughts, hurricanes, and wind events (Savill 1993). However, additional research could expand options for management. Research is needed on the mitigation of hurricane impacts (i.e., how to hurricane-proof landscapes and how to design protected areas, for example, determining what their area, shape, and distribution should be). Forest ecologists and land managers are exploring the prospects for tailoring forest management regimes to the range of ecosystem conditions and wildfire disturbance regimes observed in the past, and in some cases to those anticipated under future climate conditions. For drought, new field experiments could test forest sensitivity to specific climate-change projections in combination with changes in the concentration of atmospheric trace gases. How the genetic diversity of host plants will determine the future epidemiology of forest pathogens needs further exploration. Critical evaluations of known patterns of species change and yield following past climate changes are needed, along with models of succession that incorporate disturbance processes.

\section{Conclusions}

Over geologic time, changes in disturbance regimes are a natural part of all ecosystems. Even so, as a consequence of climate change, forests may soon face rapid alterations in the timing, intensity, frequency, and extent of disturbances. The number and complexity of climate variables related to forest disturbance make integrated research an awesome challenge. Even if changes cannot always be predicted, it is important to consider ways in which impacts to forest systems can be 
mitigated under likely changes in disturbance regimes. The task for the next decade is to understand better how climate affects disturbances and how forests respond to them. Improved monitoring programs and analytic tools are needed to develop this understanding. Ultimately, this knowledge should lead to better ways to predict and cope with disturbance-induced changes in forests.

\section{Acknowledgments}

Helpful comments on earlier drafts of this paper were provided by Linda Mann, Dick Olson, and Eric Vance. This project was supported by the National Assessment of Climate Change, the USDA Forest Service, and the Department of Energy. Oak Ridge National Laboratory is managed by UT-Battelle, LLC, for the US Department of Energy under contract DE-AC0500OR22725. This paper is Environmental Sciences Division Publication Number 4944.

\section{References cited}

Aber J. 2001. Forest processes and global environmental change: The effects of individual and multiple stressors on forests. BioScience 51: 735-751.

Ayres MP. 1993. Global change, plant defense, and herbivory. Pages 75-94 in Kareiva PK, Kingsolver JG, Huey RB, eds. Biotic Interactions and Global Change. Sunderland (MA): Sinauer Associates.

Ayres MP, Lombardero MJ. 2000. Assessing the consequences of global change for forest disturbance from herbivores and pathogens. Science of the Total Environment 262: 263-286.

Baker W. 1995. Long-term response of disturbance landscapes to human intervention and global change. Landscape Ecology 10: 143-159.

Bennetts RE, White GC, Hawksworth FG, Severs SE. 1996. The influence of dwarf mistletoe on bird communities in Colorado ponderosa pine forests. Ecological Applications 6: 899-909.

Bergeron Y, Archambault S. 1993. Decreasing frequency of forest fires in the southern boreal zone of Québec and its relation to global warming since the end of the "Little Ice Age." Holocene 5: 255-259.

Berz GA. 1993. Global warming and the insurance industry. Interdisciplinary Science Reviews 18: 120-125.

Buma J, Dehn M. 1998. A method for predicting the impact of climate change on slope stability. Environmental Geology 35: 190-196.

Dale VH, Gardner RH, DeAngelis DL, Eagar CC, Webb JW. 1991. Elevationmediated effects of balsam wooly adelgid on southern Appalachian spruce-fir forests. Canadian Journal of Forest Research 21: 1639-1648.

Dale VH, Lugo A, MacMahon J, Pickett S. 1998a. Ecosystem management in the context of large, infrequent disturbances. Ecosystems 1: 546-557.

Dale VH, King AW, Mann LK, Washington-Allen RA, McCord RA. 1998b. Assessing land use impacts on natural resources. Environmental Management 22: 203-211.

Dale VH, Joyce LA, McNulty S, Neilson RP. 2000. The interplay between climate change, forests, and disturbances. Science of the Total Environment 262: 201-204.

Daly C, Bachelet D, Lenihan JM, Parton W, Neilson RP, Ojima D. Effect of rooting depth in a dynamic vegetation model. Ecological Applications. Forthcoming.

Dehn M. Application of an analog downscaling technique to the assessment of future landslide activity: A case study in the Italian Alps. Climate Research. Forthcoming.

Easterling DR, Meehl GA, Parmesan C, Changnon SA, Karl TR, Mearns LO. 2000. Climate extremes: Observations, modeling, and impacts. Science 289: 2068-2074.

Emanuel KA. 1987. The dependence of hurricane frequency on climate. Nature 326: 483-485.

Etkin DA. 1995. Beyond the year 2000, more tornadoes in western Canada? Implications from the historical record. Natural Hazards 12: 19-27.
Flannigan MD, et al. 1998. Future wildfire in circumboreal forests in relation to global warming. Journal of Vegetation Science 9: 469-476.

Flannigan MD, Stocks BJ, Wotton BM. 2000. Climate change and forest fires. Science of the Total Environment 262: 221-229.

Franklin JF, et al. 1992. Effects of global climatic change on forests in northwestern North America. Pages 244-257 in Peters RL, Lovejoy TE, eds. The Consequences of the Greenhouse Effect for Biological Diversity. New Haven (CT): Yale University Press.

Fujita TT. 1971. Proposed characterization of tornadoes and hurricanes by area and intensity. Chicago: Department of Geophysical Sciences, University of Chicago. Satellite and Mesometeorology Research Project Paper 91.

Gehring CA, Cobb NS, Whitham TG. 1997. Three-way interactions among ectomycorrhizal mutualists, scale insects, and resistant and susceptible pinyon pines. American Naturalist 149: 824-841.

Hansen AJ, Neilson RP, Dale VH, Flather CH, Iverson LR, Currie DJ, Shafer S, Cook R, Bartlein PJ. 2001. Global change in forests: Responses of species, communities, and biomes. BioScience 51: 765-779.

Hanson PJ, Weltzin JF. 2000. Drought disturbance from climate change response of United States forests. Science of the Total Environment 262: 205-220.

Harmon ME, et al. 1986. Ecology of coarse woody debris in temperate ecosystems. Advances in Ecological Research 15: 133-302.

He HS, Mladenoff DJ, Crow TR. 1999. Linking an ecosystem model and a landscape model to study forest species response to climate warming. Ecological Modelling 114: 213-233.

Hebert PJ, Jarrell JD, Mayfield M. 1996. Deadliest, costliest, and most intense United States hurricanes of this century (and other frequently requested hurricane facts). Miami (FL): National Oceanic and Atmospheric Administration, Tropical Prediction Center. NOAA Technical Memorandum MWS-TPC-1.

Houghton JT, Meira-Filho LG, Callander BA, Harris N, Kattenberg A, Maskell K, eds. 1996. Climate Change 1995: The Science of Climate Change. New York: Cambridge University Press.

Irland LC. 1998. Ice storm 1998 and the forests of the Northeast. Journal of Forestry 96: 32-30.

- 2000. Ice storms and forest impacts. Science of the Total Environment 262: 231-242.

Karl TR, Knight RW, Plummer, N. 1995a. Trends in high-frequency climate variability in the twentieth century. Nature 377: 217-220.

Karl TR, Knight RW, Easterling DR, Quayle RG. 1995b. Indices of climate change for the United States. Bulletin of the American Meteorological Society 77: 279-292.

Kräuchi N. 1993. Potential impacts of a climate change on forest ecosystems. European Journal of Forest Pathology 23: 28-50.

Lighthill J, Holland G, Gray W, Landsea C, Craig G, Evans J, Kurihara Y, Guard C. 1994. Global climate change and tropical cyclones. Bulletin of the American Meteorological Society 75: 2147-2157.

Lugo AE. 2000. Effects and outcomes of Caribbean hurricanes in a climate change scenario. Science of the Total Environment 262: 243-251.

Lugo AE, Scatena FN. 1995. Ecosystem-level properties of the Luquillo Experimental Forest, with emphasis of the tabonuco forest. Pages 59-108 in Lugo AE, Lowe C, eds. Tropical Forests: Management and Ecology. New York: Springer-Verlag.

. 1996. Background and catastrophic tree mortality in tropical moist, wet, rain forests. Biotropica 28: 585-599.

MacCracken M, Barron E, Easterling D, Felzer B, Karl T. 2000. Scenarios for Climate Variability and Change: The Potential Consequences of Climate Variability and Change for the United States. Washington (DC): US Global Change Research Program, National Science Foundation.

Mack MC, D’Antonio CM. 1998. Impacts of biological invasions on disturbance regimes. Tree 13: 195-198.

Marsinko AP, Straka TJ, Haight RG. 1997. The effect of large-scale natural disaster on regional timber supply. Journal of World Forest Resource Management 8: 75-85. 
Michaels G, Cherpack J. 1998. Ice Storm Ravages Northern Forests. Washington (DC): National Association of Conservation Districts. Forestry Notes 7.

[NAST] National Assessment Synthesis Team. 2000. Climate Change Impacts on the United States: The Potential Consequences of Climate Variability and Change. Washington (DC): US Global Change Research Program.

Negron JF. 1998. Probability of infestation and extent of mortality associated with the Douglas-fir beetle in the Colorado Front Range. Forest Ecology and Management 107: 71-85.

Neilson RP, Drapek RJ. 1998. Potentially complex biosphere responses to transient global warming. Global Change Biology 4: 505-521.

Ojima DS, Kittel TGF, Rosswall T, Walker BH. 1991. Critical issues for understanding global change effects on terrestrial ecosystems. Ecological Applications 1:316-325.

Opler PA. 1979. Insects of American chestnut: Possible importance and conservation concern. Pages 83-85 in McDonald W, ed. The American Chestnut Symposium. Morgantown (WV): University of West Virginia Press.

Paine RT, Tegner MJ, Johnson AE. 1998. Compounded perturbations yield ecological surprises: Everything else is business as usual. Ecosystems 1: 535-545.

Peterson C. 2000. Catastrophic wind damage to North American forests and the potential impact of climate change. Science of the Total Environment 262: 287-311.

Peterson CJ, Pickett STA. 1995. Forest reorganization: A case study in an oldgrowth forest catastrophic blowdown. Ecology 76: 763-774.

Reeve JR, Ayres MP, Lorio PL Jr. 1995. Host suitability, predation, and bark beetle population dynamics. Pages 339-357 in Cappuccino N, Price PW, eds. Population Dynamics: New Approaches and Synthesis. San Diego (CA): Academic Press.

Royer JF, Chauvin F, Timbal B, Araspin P, Grimal D. 1998. A GCM study of the impact of greenhouse gas increase on the frequency of occurrence of tropical cyclones. Climatic Change 38: 307-343.

Ruiz RV. 1996. Forest fires and their social and economic impacts. Pages 49-53 in Ffolliott PF, DeBano LF, Baker MB Jr, Gottfried GJ, Solis-Garza G, Edminster CB, Neary, DG, Allen LS, Hamre RJ, coordinators. Effects of Fire on Madrean Province Ecosystems: A Symposium Proceedings. Washington (DC): USDA Forest Service. Publication RM-GTR-289.

Savely HE. 1939. Ecological relations of certain animals in dead pine and oak logs. Ecological Monographs 9: 321-385.

Savill PS. 1993. Silviculture in windy climates. Commonwealth Forestry Abstracts 44: 473-488.
Schuster RL. 1996. Socioeconomic significance of landslides. Pages 12-35 in Turner AK, Schuster RL, eds. Landslides: Investigation and Mitigation. Washington (DC): National Academy Press. Transportation Research Board Special Report 247.

Segal MR, Avissar R, McCumber MC, Pielke RA. 1988. Evaluation of vegetation effects on the generation and modification of mesoscale circulation. Journal of Atmospheric Science 45: 2268-2392.

Simberloff D. 1997. The biology of invasions. Pages 3-17 in Simberloff D, Schmitz D, Brown T, eds. Strangers in Paradise: Impact and Management of Nonindigenous Species in Florida. Washington (DC): Island Press.

2000. Global climate change and introduced species in United States forests. Science of the Total Environment 262: 253-261.

Smith WH. 2000. Ice and forest health. Northern Journal of Applied Forestry. 17: 16-19.

Stocks BJ, et al. 1998. Climate change and forest fire potential in Russian and Canadian boreal forests. Climatic Change 38: 1-13.

Stone WE, Wolfe ML. 1996. Response of understory vegetation to variable tree mortality following a mountain pine beetle epidemic in lodgepole pine stands in northern Utah. Vegetatio 122: 1-12.

Turner MG, et al. 1998. Factors influencing succession: Lessons from large, infrequent natural disturbances. Ecosystems 1: 511-523.

Ungerer MJ, Ayres MP, Lombardero MJ. 1999. Climate and the northern distribution limits of Dendroctonus frontalis Zimmerman (Coleoptera: Scolytidae). Journal of Biogeography 26: 1133-1145.

[USDA] US Department of Agriculture. 1990. An analysis of the timber situation in the United States: 1989-2040. Washington (DC): USDA. Publication RM-GTR-199.

- 1997. Forest insect and disease conditions in the United States 1996. Washington (DC): USDA Forest Service, Forest Health Protection.

Walsh K, Pittock AB. 1998. Potential changes in tropical storms, hurricanes, and extreme rainfall events as a result of climate change. Climatic Change 39: 199-213.

Walters C. 1986. Adaptive Management of Renewable Resources. New York: Macmillan.

Weir JMH. 1996. The Fire Frequency and Age Mosaic of a Mixed Wood Boreal Forest. Master's thesis. University of Calgary, Calgary, Canada.

Whelan RJ. 1995. The Ecology of Fire. Cambridge (UK): Cambridge University Press.

Wilf P, Labandeira CC. 1999. Response of plant-insect associations to Paleocene-Eocence warming. Science 284: 2153-2156.

Williamson M. 1999. Invasions. Ecography 22: 5-12. 